\title{
CHAPTER
}

\section{SHOWCASING ENTREPRENEURS' RESPONSES TO SEVERE DROUGHT: QUALITATIVE FINDINGS FROM CAPE TOWN, SOUTH AFRICA}

Florine M. Kuijpers ${ }^{1}$ and Emiel L. Eijdenberg ${ }^{2}$

${ }^{1}$ Independent Researcher, Amsterdam, The Netherlands

${ }^{2}$ Business, IT and Science Department, James Cook University, Singapore, Singapore

\subsection{CONTEXTUALIZATION: DROUGHT AND ENTREPRENEURSHIP}

That South Africa science pushes to improve daily life does not come as a surprise. Apart from the emerging country's social and economic struggles, climate change leaves its traces as exemplified by severe drought (Wild, 2018). "Drought is a natural hazard and recurrent feature of southern Africa's climate" (Baudoin, Vogel, Nortje, \& Naik, 2017, p. 129). Without doubt, South Africa-especially the Western Cape region, in and around Cape Town-has been suffering from drought for years. Some blame solely climate change (e.g., Baudoin et al., 2017; Botai, Botai, Wit, de, Ncongwane, \& Adeola, 2017; Chersich et al., 2018; Favretto, Dougill, Stringer, Afionis, \& Quinn, 2018; Schiermeier, 2018); others blame failure of people in the government and market sector acting upon ecological challenges (Muller, 2018). The fact is that the environment is changing and scholars call for more research on how society should respond to those changes (Flatø, Muttarak, \& Pelser, 2017; Sershen et al., 2016; Vogel \& Olivier, 2018; Zwane, 2019).

Different research perspectives (e.g., development economics, see Mare, Bahta, \& van Niekerk, 2018; Mdungela, Bahta, \& Jordaan, 2017; ecological, see Dos Santos, 2016; Vogel \& Olivier, 2018; societal, see Flatø et al., 2017; sustainability, see Favretto et al., 2018) have shed light on the effects of drought and society's response to it. However, the entrepreneurship perspective has largely been overlooked. Entrepreneurship, seen as the establishment of organizations and those who establish them are the entrepreneurs (Gartner, 1988), is key for social and economic development (Audretsch, Keilbach, \& Lehmann, 2006; Baumol \& Strom, 2007; Powell, 2008). Admittedly, entrepreneurship "impacts economic performance at the individual, firm and societal 
levels, affecting personal wealth, firm profitability, and economic growth" (Wennekers, Uhlaner, \& Thurik, 2002, p. 27). This impact is especially important for the world's emerging contexts such as South Africa.

Understandings of entrepreneurship are not a one size fit all (Annink, Den Dulk, \& Amorós, 2016; Eijdenberg, 2016). In recent years, contextualization has received an increased attention from scholars in entrepreneurship research (Welter, 2011; Welter, Baker, Audretsch, \& Gartner, 2017; Welter, Kautonen, Chepurenko, Malieva, \& Venesaar, 2004; Zahra, Wright, \& Abdelgawad, 2014). One way of contextualizing entrepreneurship is examining the role of institutional environments, especially in ecological terms. This type of research has facilitated perspectives on entrepreneurship in different ways, for example, in terms of its challenges and how entrepreneurs respond to these challenges (Eijdenberg, Thompson, Verduijn, \& Essers, 2019). However, most of this research is conducted on macro- (i.e., society) and meso- (i.e., sector, community) levels, often based on large sample surveys and cross-country comparative studies (Manolova, Eunni, \& Gyoshev, 2008; Stenholm, Acs, \& Wuebker, 2013).

Despite the valuable insights that the macro- and meso-level studies have brought forth (e.g., cultural and economic effects, see Aparicio, Urbano, \& Audretsch, 2016; Naudé, Gries, Wood, \& Meintjies, 2008; Urbano \& Alvarez, 2014), little is known about entrepreneurial activities on the micro-level, that is, the personal stories and experiences of entrepreneurs who act in, for example, emerging countries. Institutional theory helps to understand these activities in terms of untangling a context into different components (e.g., cultural, economic, and political) (Shane, 2003; Welter \& Smallbone, 2011).

Institutional theory is instrumental indeed to link the macro-micro-level dimensions, and, therefore, shed more light on how macro-level factors affect micro-level activities (Oliver, 1991; Welter \& Smallbone, 2011; Wicks, 2001). This way, entrepreneurial activities are made more mundane and this is vital to know from the world's under-researched areas: emerging countries. The aim of this chapter is to reveal entrepreneurial activities by focusing on the responses of 12 entrepreneurs to the institutional challenge of a natural disaster: severe drought. This is done in the emerging context of Cape Town, South Africa, during and just after three years of severe drought. The following research question will be answered: "How do entrepreneurs in an emerging context deal with the ecological challenge of severe drought?"

Following calls for more qualitative insights (Bruton, Ahlstrom, \& Li, 2010), this chapter makes two contributions to theory. First, the main contribution is following up to calls for more contextualization of entrepreneurship (Weerawardena \& Mort, 2006; Welter \& Smallbone, 2011; Welter et al., 2017; Welter, 2011). By doing so, the mundane activities of entrepreneurs will overcome the disconnection of macro- and micro-level research (Eijdenberg et al., 2019; Greenman, 2013; Manolova \& Yan, 2002; Stenholm et al., 2013; Urbano \& Alvarez, 2014; Wicks, 2001). Second, this study expands the "conventional" institutional challenges (i.e., cultural, economic, political) (cf. Eijdenberg et al., 2019; Griffiths, Gundry, \& Kickul, 2013) by adding ecological challenges into the equation. Entrepreneurs respond in three ways: (1) personal solutions; (2) improvised solutions of water management; and (3) professional solutions of water management. This chapter unfolds these types of responses by highlighting many different personal stories and experiences. Hereafter, the relevant literature will be discussed, followed by the methodology. Subsequently, the study's findings are discussed. The chapter closes with a discussion and conclusion. 


\subsection{BACKGROUND LITERATURE}

\subsubsection{INSTITUTIONAL THEORY IN ENTREPRENEURSHIP RESEARCH}

Institutional theory introduces a unique approach regarding the study of social, economic, and political dynamics (DiMaggio \& Powell, 2000). Institutions form the rules of the game within society (North, 1991). Formal as well as informal institutions, for example, the extended family, the private sector and the government, are part of those rules. New institutional insights are building on sociological traditional theories (DiMaggio \& Powell, 1983; Scott, 1995). These new insights emphasize the role of the operating institutional context, which are considered to shape enterprises and the behavior of entrepreneurs (Scott, 1995).

When the institutional structure is operating appropriately, it can reduce transaction costs, uncertainty, and risk for entrepreneurs. Legal structures also determine the ease of entering markets and influence bankruptcy laws. Contrarily, a weak or unsatisfactory legal structure may constrain development. Particularly, where institutional gaps leave room for arbitrary behavior, this may lead to corruption and objective behavior of entrepreneurs (Puffer, McCarthy, \& Boisot, 2010; Smallbone \& Welter, 2001). In addition, informal relationships, such as local networks, arise as a result of institutional constraints (Khanna \& Palepu, 1997). As a result, entrepreneurship can appear while not being legally recognized (Klapper, Laeven, \& Rajan, 2006).

Institutional theory has received increased attention in entrepreneurship research; however, most of them taking place in developed countries. Conversely, emerging contexts are gaining stage regarding institutional theory-led research. Most of this type of research has shed light on the aspects of the market and government failure of countries, therefore, providing room for different types of entrepreneurs to operate (Littlewood \& Holt, 2018; Rivera-Santos, Holt, Littlewood, \& Kolk, 2015). Examples of aspects are the aging infrastructure; static-centric systems; retained government control in the private sector and land ownership; limited access to information; and bureaucratic procedures to start new enterprises (Central Intelligence Agency, 2019; Saini \& Bhatia, 1996; World Bank, 2019a). Although interviewing every entrepreneur in a country is unrealistic, attempts have been made to hear personal stories of them about operating enterprises in emerging contexts (cf. Abdallah \& Eijdenberg, 2019; Eijdenberg et al., 2019; Khavul, Bruton, \& Wood, 2009; Littlewood \& Holt, 2018). By hearing these stories the link between macro and micro is made, making entrepreneurial activities in the world's underrepresented research areas come alive.

\subsubsection{ECOLOGICAL CHALLENGES OF ENTREPRENEURS IN SOUTH AFRICA}

From an institutional theory perspective, effective drought management can be hampered by complicated bureaucratic procedures, static-centric institutions, slow top-down management, corruption, lack of transparency and accountability of the institutions, and poor infrastructure (Baudoin et al., 2017). The government, as guardian of the country's citizens, plays a key role in this. South Africa has been suffering from many of the previously mentioned factors that all led to dramatic societal consequences such as destroyed farmlands and malnutrition of people. In the past, drought management has only been implemented after times of drought, not during or as a precautionary measure (Baudoin et al., 2017; Favretto et al., 2018). Recently, an increasing number of official, 
government-led arrangements have been made such as new legislation on water management, policies, warning systems, support programs, trainings, and water management equipment for farmers, private sector and citizens-all with moderate success (Bahta, Jordaan, \& Muyambo, 2016; Baudoin et al., 2017; Mare et al., 2018).

Nevertheless, from an entrepreneurship perspective, commercial farmers have often been subjected to broad-sample surveys on the effects of drought and their responses thereof (e.g., Bahta et al., 2016; Mdungela et al., 2017; Mutero, Munapo, \& Seaketso, 2016). Indeed, as being highly dependent on climate, farmers-if perceived as entrepreneurs anyways - are probably the ones hit first by drought. Multiple consequences of drought to farmers are reported, for example, lack of resources, unemployment, price sensitivity, and the lack of financial safety nets (Mdungela et al., 2017); and inadequate government support, psychological stress, and high levels of stock theft (Bahta et al., 2016). The provision of basic tools is often the key to acquire some sort of irrigation and improved management, and, hence, business viability and continuation (Mutero et al., 2016). Similar patterns (i.e., business viability and continuation based on basic entrepreneurial tools and skills) are found by different types of entrepreneurs in other African emerging countries (cf. Choongo, 2017; Eijdenberg et al., 2019; Khavul et al., 2009). However, the entrepreneurship perspective-especially connecting macro-level events to micro-level activities, based on qualitative data-is hardly applied in the context of ecological challenges such as drought.

\subsection{METHODOLOGY}

\subsubsection{RESEARCH CONTEXT: CAPE TOWN, SOUTH AFRICA}

South Africa has one of the oldest notions of human civilization and has a long history of colonization before it received full independence from the United Kingdom in 1931. Through history, the country has had different ethnic groups (e.g., Asians, Europeans, indigenous Bantu peoples) living together on 1.2 million square kilometers (Central Intelligence Agency, 2019).

With respect to all aspects of South Africa's history in the 20th century, a huge leap brings us to 2010: the year that South Africa entered the league of so-called BRICS (Brazil, Russia, India, China, and South Africa), that is, the five major emerging economies of the world (Bremmer, 2017). To illustrate the economic situation, South Africa's estimated population of 55 million makes up for a gross domestic product of USD 767 billion (i.e., USD 13,600 per capita-in comparison with, e.g., the United States: USD 59,800). The country is rich in natural resources, and well-developed manufacturing and services sectors. However, in recent years, economic growth has decelerated and unemployment (i.e., 27.5\%), poverty (i.e., 16.6\% lives below the poverty line) and inequality in the post-apartheid era have hindered the country's social and economic progression (Carter \& May, 2001; Central Intelligence Agency, 2019; Durrheim, Mtose, \& Brown, 2011).

South Africa is one of the world's most unequal countries, having a 63.0 score on the Gini Index in 2014 (World Bank, 2019b). Typical social issues in South Africa are significant numbers of an unskilled and low-educated workforce; high crime rates; and the highest HIV/AIDS numbers of the world (Central Intelligence Agency, 2019). Moreover, the country has been showing concerning numbers in comparison with the entire sub-Saharan region in terms of perceived opportunities, entrepreneurial intentions, entrepreneurial activity, and established business ownership 
(Global Entrepreneurship Monitor, 2019b). For example, the percentage of the 18-64 population (individuals involved in any stage of entrepreneurial activity excluded) who are latent entrepreneurs and who intend to start a business within three years is $12.76 \%$ (2013) - in comparison, Botswana is $20.85 \%$, Malawi is $28.11 \%$, Namibia $33.34 \%$, and Zambia is $39.91 \%$, in the same year (Global Entrepreneurship Monitor, 2019a).

Conversely, entrepreneurs in emerging contexts such as South Africa are important because they move economic development forward (Naudé et al., 2008). Like elsewhere, entrepreneurs in South Africa address global trends (e.g., innovation, mobility, sustainability) and provide improvised solutions to them (e.g., frugal innovations ${ }^{1}$ ).

\subsubsection{RESEARCH DESIGN}

As the aim of this explorative study is to showcase the personal responses of entrepreneurs to drought in an emerging context, a qualitative research approach was chosen. "The qualitative researchers study things in their natural settings, attempting to make sense of, or interpret, phenomena in terms of the meanings people bring to them" (Denzin \& Lincoln, 2011, p. 3). This approach fits with the aim of the study to get an understanding of entrepreneurs' experiences, feelings, and perceptions. For the same reason, this study follows a phenomenological approach (Groenewald, 2004; Yin, 2009).

The data were collected from individual interviews with entrepreneurs, active in different industries. Taking Gephart (2004) as the point of departure, the aim of the individual interviews was to collect inductive data on environmental challenges and entrepreneurs' responses to those challenges. Semi-structured interviews with open-ended questions were conducted, which led to an in-depth interview, which was recorded and transcribed. The advantage of the individual interview is the in-depth, detailed, and personal aspect. In addition, the interviewer is able to elaborate extensively on personal stories. The use of probing questions and follow-up questions results in a deeper understanding of the studied phenomena (Bryman, 2016; Saunders, Lewis, \& Thornhill, 2016).

\subsubsection{SAMPLE SELECTION}

The data stems from entrepreneurs in Cape Town. Amongst other major urban areas such as Johannesburg, Durban, and Pretoria, Cape Town is the country's legislative capital of 4.4 million inhabitants. In addition, Cape Town is one of the major tourist destinations of South Africa. Much entrepreneurial activity has grown in this city because of its branches of different multinational enterprises and its ideal central location with a large harbor and airport (Cape Town Tourism, 2018; Central Intelligence Agency, 2019; World Bank, 2017). Cape Town is leading in ease of doing business compared to other cities in South Africa (World Bank, 2019a). Apart from its strategic location, since 2015 Cape Town has been suffering from severe drought that has peaked in mid-2017 and mid-2018 (City of Cape Town, 2019; Climate System Analysis Group, 2019) impacting daily life significantly.

\footnotetext{
${ }^{1}$ Frugal innovations are typically not perfect, rather acceptable. They represent affordable products or services that sufficiently meet the needs of resource-constrained consumers who have no access to more expensive alternatives, see Hossain (2018) and Khan (2016).
} 
A generic purposive sampling technique was used to select respondents for the interviews (Saunders et al., 2016). The "Social Enterprise Academy South Africa" facilitated a list of enterprises based in Cape Town (Social Enterprise Academy South Africa, 2019). This initiative monitors social entrepreneurial activity in Cape Town with the objective of learning for enterprises to increase their social impact and financial sustainability. This initial sample of 80 enterprises was the point of departure for further selection: 50 enterprises were contacted randomly of which $20 \%$ responded to cooperate. In addition, two other interviews were conducted based on snowball sampling (Mey \& Smit, 2013): "snowballing involves recruiting individuals to collect data from other individuals whom they think meet certain inclusion criterion defined by the researcher" (McGee, Peterson, Mueller, \& Sequeira, 2009, p. 974). Thus, a total of 12 interviews was conducted, a sufficient number to achieve saturation level in qualitative research (Saunders et al., 2016). The respondents' selection criteria were (1) the total number of respondents had to represent an equal gender-balance of female and male entrepreneurs; (2) each respondent had to be the founder of the enterprise, but in case the founder was not anymore involved, the successor or board member was selected; (3) the respondents had to be from different industries to achieve heterogeneity of the sample; and (4) both the enterprises and its entrepreneurs had to be based in Cape Town. Table 9.1 presents the most relevant pertinent information of the respondents.

\subsubsection{DATA COLLECTION}

After the sample selection, the first author of this chapter (hereafter referred to as "the researcher") collected the qualitative data by online, face-to-face video interviews using Facetime, Google Hangouts, and Skype. The data were collected in December 2018 and January 2019. The researcher used one semi-structured interview guide. The interviews revolved around the following main question: "How have you and your business dealt with the effects of drought in Cape Town, South Africa?". Naturally, deviations from this question occurred (e.g., follow up questions and probes) to structure the interview.

The 12 interviews were conducted in English. The interviews took on average 45 minutes; however, significant deviations in time occurred because certain entrepreneurs conducted the interview during operation hours of their business. While all entrepreneurs were located in the wider Cape Town region, the majority of them were located in the business district of Cape Town (i.e., "Cape Town CBD" or "City Bowl" area). Exceptions were townships and other parts of the city, usually with poorer Internet connectivity. All interviews were recorded and afterward transcribed intelligent verbatim.

\subsubsection{DATA ANALYSIS}

After the data were collected and transcribed the analyses were conducted. An inductive analysis approach was used, following the "Gioia methodology" (Gehman et al., 2018; Gioia, Corley, \& Hamilton, 2013). In this way, credible interpretations of data were established through systematic conceptual and analytical discipline. This methodology brings qualitative rigor and transparency to inductive research and it has previously been applied in other African contexts (cf. Eijdenberg et al., 2019). First, the first-order concepts were formulated (a reduced number of words of a quotation or observation) by coding the 12 interviews. Second, these first-order concepts were 


\begin{tabular}{|c|c|c|c|c|c|c|}
\hline $\begin{array}{l}\text { Respondent } \\
\text { Number }\end{array}$ & Gender & Age & $\begin{array}{l}\text { Position } \\
\text { Within } \\
\text { Business }\end{array}$ & $\begin{array}{l}\text { Founding } \\
\text { Year of } \\
\text { Business }\end{array}$ & $\begin{array}{l}\text { Number of } \\
\text { Employees } \\
\text { at Time of } \\
\text { Interview }\end{array}$ & Industry \\
\hline $1^{\mathrm{b}}$ & Male & 26 & $\begin{array}{l}\text { Responsible for } \\
\text { social enterprises }\end{array}$ & 1981 & 15 & Education \\
\hline 2 & Female & 49 & Founder & 1981 & 15 & Education \\
\hline 3 & Male & 24 & Founder & 2018 & $2-10$ & Agriculture \\
\hline 4 & Male & 24 & Founder & 2014 & $2-10$ & Education \\
\hline 5 & Male & 45 & Founder & 2004 & 15 & Entertainment \\
\hline 6 & Female & 39 & Founder & 2012 & 5 & Entertainment \\
\hline 7 & Male & 44 & Founder & 2014 & $2-10$ & Education \\
\hline 8 & Male & 43 & Director & 1997 & 25 & Education \\
\hline 9 & Female & 60 & Founder & 1992 & $51-200$ & $\begin{array}{l}\text { Disability } \\
\text { service }\end{array}$ \\
\hline 10 & Female & 34 & Cofounder & 2017 & $2-10$ & Education \\
\hline 11 & Female & 49 & Cofounder & 2010 & 75 & Retail \\
\hline 12 & Female & 28 & Founder & 2016 & 9 & Education \\
\hline
\end{tabular}

categorized into 15 second-order codes. Third, based on the second-order codes three aggregate dimensions were generated: "personal solutions," "improvised solutions of water management," and "professional solutions of water management."

\subsection{FINDINGS}

The three themes (i.e., "personal solutions," "improvised solutions of water management," and "professional solutions of water management") are presented in Fig. 9.1. This figure is supported by exemplary quotes. These quotes are presented in Table 9.2.

Cape Town's drought has influenced respondents in effectively running their enterprises. To illustrate, all inhabitants of Cape Town were allowed to use only $20 \mathrm{~L}$ of water per person per day and businesses had water restrictions imposed. Respondents reported that they were not able to manage their businesses as before the drought. For example, donated clothes could not be washed properly since washing machines were using too much water (respondent 8). In addition, Cape Town's environment changed: respondents were not able to enter certain parts of townships anymore because of safety reasons due to drought. This has limited business operations, causing declining sales. 


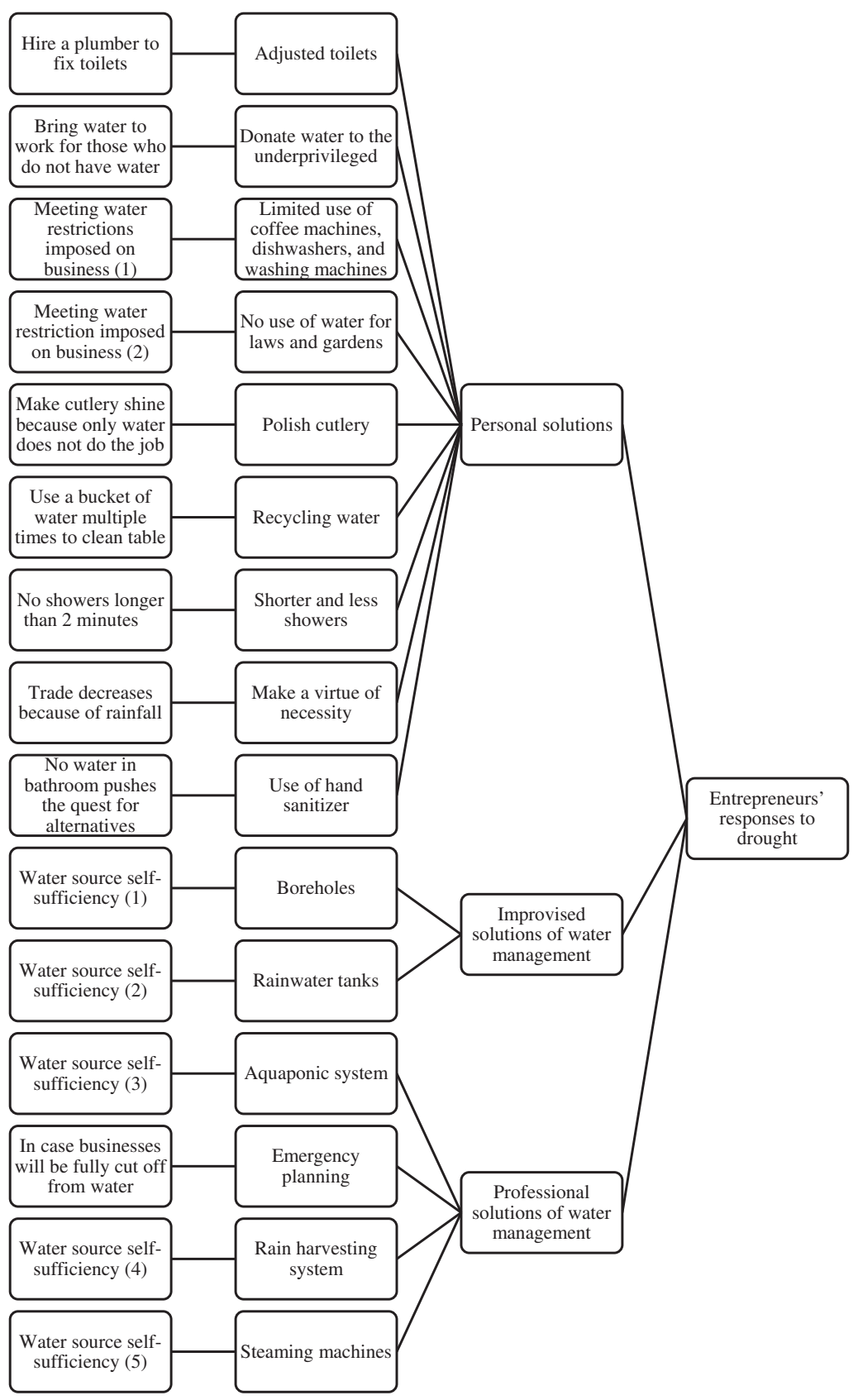

FIGURE 9.1

Entrepreneurs' responses to drought. 
Table 9.2 Exemplary Quotes of Entrepreneurs' Responses.

\section{Exemplary Quote of First-Order Quote}

"We had the plumber coming in so that the toilets wouldn't flush as strongly, because we had really old toilets in this building, it would still flush properly, but not as fast, like those type of things."

"Yeah! Saving the water, bringing water to work to help people who didn't have water; it's just part of work."

"So, we were going from doing 20 loads of washing a day to doing six or seven loads of washing a day, because we couldn't fit into the water restrictions that were imposed on us. We had to change all of our machines because the previous machines were using too much water."

"For the business what we did was, so normally young adults would polish the cutlery and stuff like that, and they do that with water. So, the cutlery is washed in the dishwasher, but to make it shiny, we still polish it."

"Normally they would fill a whole bucket and then just clean the table once and then throw that water away. So, same story, I would tell them: 'No, you must use that at least a couple of times until it's dirty, otherwise it's a waste of water."'

"I mean, up until a couple of weeks ago and don't think I've had a shower longer than two minutes for more than a year."

"What did happen was with the sales booming in our program, they had a really good sales winter, because in Cape Town it rains in winter. So, most traders are informal. So, in winter their sales often drops because of the raining, and so they can't get our things traded. So, they actually did quite well with their trading in the winter that we didn't had [have] much rain. So, it's sort of a benefit of being in a kind of funny sense."

"With regards to the droughts, obviously there was the general things of not having water in the bathrooms and having to use hand sanitizer for example, and that sort of thing."

"We're far more water source self-sufficient and we've got a borehole so and we're still trying to come close to Table Mountain so we got beautiful mountain water into the borehole."

"The strength of the drought was obviously a concern for us which we responded to immediately so well, our properties have proper rainwater tanks and so that should safe some."

"An aquaponic system is a method to grow food, in which aquaculture, the growth of aquatic animals, is combined in a symbiotic way with hydroponics, the cultivation of plants in water. Fish provide the necessary nutrients for plant growth and the plant roots filter the water for the fish. Therefore, aquaponic creates its own ecosystem, without the need of adding non-ecological plant nutrients. Water with the nutrients from the fish is pumped into a grow bed. Plants filter the water, which is being pumped into the sump tank and back into the fish tank. And one of the major benefits of the system is that it saves up to $90 \%$ of water in comparison to growing vegetables in regular fertile soil."

\section{Second-Order Code}

Adjusted toilets

Donate water to the underprivileged

Limited use of coffee machines, dishwashers and washing machines

Polish cutlery

Recycling water

Shorter and less showers

Make a virtue of necessity

Use of hand sanitizer

Boreholes

Rainwater tanks

Aquaponic system 


\begin{tabular}{|l|l|}
\hline Table 9.2 Exemplary Quotes of Entrepreneurs' Responses. Continued \\
Exemplary Quote of First-Order Quote & Second-Order Code \\
"Because it would be a nightmare if we were cut off, imagine all \\
the bathrooms, and with like 100 people in and out here all day, \\
it would be a disaster. So, we made a plan in case 'Day Zero' came." \\
"We had to put in a rain harvesting system, so that when it does rain, \\
we can catch that in a tank and use that." \\
"We had to buy steaming machines so that we could steam stuff \\
$\begin{array}{l}\text { that weren't [...] And it costed us 60.000 Rand to do that. A few } \\
\text { months later, we did two more water tanks at our cellar centre } \\
\text { that was another } 10.000 \text { Rand. Let's call it 70.000 Rand. It's } \\
\text { not insignificant for us, but we just had to do that, we couldn't } \\
\text { avoid it." }\end{array}$ \\
\hline
\end{tabular}

Personal solutions from entrepreneurs were exemplified by the many things they could do with their bare hands or required little time and resources. For example, hiring a plumber to adjust the toilets not to flush as strongly (respondent 12); donating water on work to those who do not have access to water (respondent 9); and using hand sanitizer as an alternative for traditional washing hands in the bathroom (respondent 10).

At the business level, two types of solutions of water management were discussed. First, improvised solutions were made to contribute with as limited resources as possible such as making boreholes (respondent 2) and installing "Jojo" rainwater tanks (respondent 11) (see for a description: Jojo, 2019). Second, more professional solutions were made such as an aquaponic system (see Table 9.2 for a description from the data and see, e.g., Mchunu, Lagerwall, \& Senzanje, 2018 for a literary reference) (respondent 3), rain harvesting systems and steaming machines (respondent 8). However, the professional solutions often come at a financial premium that means they are not feasible for all entrepreneurs.

\subsection{DISCUSSION}

\subsubsection{CONTRIBUTION TO THE LITERATURE}

The main contribution of this chapter is following up to calls for more contextualization of entrepreneurship (Weerawardena \& Mort, 2006; Welter \& Smallbone, 2011; Welter et al., 2017; Welter, 2011). By doing so, the mundane activities of entrepreneurs as showcased in the Findings section overcome the disconnection of macro- and micro-level research (Eijdenberg et al., 2019; Greenman, 2013; Manolova \& Yan, 2002; Stenholm et al., 2013; Urbano \& Alvarez, 2014; Wicks, 2001). This is of great value because it provides more lively and tangible examples, catering for better theoretical and practical solutions. Within contextualization, this chapter adds onto the calls for more research of emerging countries in Africa (George, 2015; George, Corbishley, Khayesi, 
Haas, \& Tihanyi, 2016; Khavul et al., 2009; Khayesi, George, \& Antonakis, 2014; Littlewood \& Holt, 2015, 2018; Rivera-Santos et al., 2015).

On a more granular level the second contribution is that this chapter expands the "conventional" institutional challenges (i.e., cultural, economic, political) (cf. Eijdenberg et al., 2019; Griffiths et al., 2013) by adding ecological challenges into the equation. Obviously, ecological challenges themselves are not new, nor the sustainable solutions to them in emerging countries (e.g., Askham, \& Van der Poll, 2017; Choongo, 2017; Choongo, van Burg, Masurel, Paas, \& Lungu, 2017; Mabhaudhi et al., 2019). However, the entrepreneurs' responses to those challenges, from an institutional theory perspective, are novel-especially in the case of the recent drought in the Cape Town region. These responses contain many detailed, contextual examples, providing a closer look at real activities of entrepreneurs during and after times of a natural disaster.

\subsubsection{LIMITATIONS AND RECOMMENDATIONS FOR FUTURE RESEARCH}

Taking the findings of the second-order codes and the three aggregate themes as such, they are limited by the used methodology; sample selection, size, and location; and time of the data collection. Obviously, different findings are produced when these limitations are overcome. Therefore, future researchers are encouraged to fill out more qualitative findings by, for example, conducting triangulation and researching other cases in different settings and times (Saunders et al., 2016). Especially, the aggregated theme of ecological challenges and the entrepreneurs' responses thereof should receive more scholarly attention because this is clearly found as an addition to previously mentioned "conventional" institutional challenges (i.e., cultural, economic, political) (cf. Abdallah \& Eijdenberg, 2019; Eijdenberg et al., 2019).

Moreover, as this study follows up on institutional theory and entrepreneurship in emerging countries (e.g., Eijdenberg et al., 2019; Littlewood \& Holt, 2015, 2018; Rivera-Santos et al., 2015), future researchers are encouraged to move this type of research from a qualitative to a quantitative methodological fashion (Edmondson \& McManus, 2007). Indeed, qualitative research such as the current study yields rich, proto-typical, and exemplary findings from South Africa's emerging context; however, future research should also contain events and patterns that are generalizable to a certain extent, and, therefore, surveying entrepreneurs would be the next methodological step.

\subsubsection{IMPLICATIONS FOR PRACTICE}

The practical relevance of this chapter reflects in multiple ways. First, on a general level, this chapter stimulates the debate about what it means to entrepreneurs to overcome the effects of drought in South Africa. This can be done, for example, already on primary and secondary school: developing children's entrepreneurial skills to think of and create improvised solutions (e.g., boreholes, rainwater tanks) of water management. Moreover, also the current existing cohort of entrepreneurs in South Africa, or elsewhere in the world, can take lessons from their peers to overcome the effects of natural disasters. For example, educators can teach entrepreneurs to become more self-sufficient and efficient by using water (e.g., less use of coffee machines, dishwashers, and washing machines; using hand sanitizer; polish cutlery as a way to use less water). In that way, children and entrepreneurs will be more prepared and resilient to natural crises which is something, unfortunately, has to be taken into account for the future because of climate change. 


\section{CHAPTER 9 SHOWCASING ENTREPRENEURS' RESPONSES}

\subsection{CONCLUSION}

The aim of this chapter was to give an answer to the research question "How do entrepreneurs in an emerging context deal with the ecological challenge of severe drought?" by studying the interplay between the institutional context and entrepreneurship from a micro-level perspective within the context of Cape Town, South Africa. The ecological challenges due to recent drought play a key role in everyday entrepreneurial life. Entrepreneurs respond to the challenges in three ways: (1) personal solutions; (2) improvised solutions of water management; and (3) professional solutions of water management. In addition to the literature, this chapter showcases the mundane activities of entrepreneurs in an emerging context during and after times of a natural disaster, that is, severe drought. By doing so, more contextualization of entrepreneurship is given (Welter \& Smallbone, 2011; Welter et al., 2017; Welter, 2011), bridging the gap between macro- and micro-level research (Eijdenberg et al., 2019; Manolova et al., 2008; Stenholm et al., 2013).

\section{REFERENCES}

Abdallah, G. K., \& Eijdenberg, E. L. (2019). Entry and stay in the informal economy: Qualitative findings from a least developed country. Journal of Enterprising Culture, 27(2), 115-145.

Annink, A., Den Dulk, L., \& Amorós, J. E. (2016). Different strokes for different folks? The impact of heterogeneity in work characteristics and country contexts on work-life balance among the self-employed. International Journal of Entrepreneurial Behavior \& Research, 22(6), 880-902.

Aparicio, S., Urbano, D., \& Audretsch, D. (2016). Institutional factors, opportunity entrepreneurship and economic growth: Panel data evidence. Technological Forecasting and Social Change, 102, 45-61.

Askham, T. M., \& Van der Poll, Huibrecht, M. (2017). Water sustainability of selected mining companies in South Africa. Sustainability, 9(6), 957.

Audretsch, D. B., Keilbach, M. C., \& Lehmann, E. E. (2006). Entrepreneurship and economic growth. Oxford: Oxford University Press.

Bahta, Y. T., Jordaan, A., \& Muyambo, F. (2016). Communal farmers' perception of drought in South Africa: Policy implication for drought risk reduction. International Journal of Disaster Risk Reduction, 20, 39-50.

Baudoin, M. A., Vogel, C., Nortje, K., \& Naik, M. (2017). Living with drought in South Africa: Lessons learnt from the recent El Niño drought period. International Journal of Disaster Risk Reduction, 23, 128-137.

Baumol, W. J., \& Strom, R. J. (2007). Entrepreneurship and economic growth. Strategic Entrepreneurship Journal, 1(3-4), 233-237.

Botai, C. M., Botai, J. O., De Wit, J. P., Ncongwane, K. P., \& Adeola, A. M. (2017). Drought characteristics over the Western Cape Province, South Africa. Water, 9(11), 876.

Bremmer, I. (2017). The mixed fortunes of the BRICS countries, in 5 facts. Retrieved from < http://time.com/ 4923837/brics-summit-xiamen-mixed-fortunes/>.

Bruton, G. D., Ahlstrom, D., \& Li, H.-L. (2010). Institutional theory and entrepreneurship: Where are we now and where do we need to move in the future? Entrepreneurship Theory and Practice, 34(3), 421-440.

Bryman, A. (2016). Social research methods. Oxford: Oxford University Press.

Cape Town Tourism. (2018). Annual report 2017/2018. Retrieved from <https://www.capetown.travel/wpcontent/uploads/2018/10/Annual-Report-20172018.pdf>.

Carter, M. R., \& May, J. (2001). One kind of freedom: Poverty dynamics in post-apartheid South Africa. World Development, 29(12), 1987-2006. 
Central Intelligence Agency. (2019). The world factbook: South Africa. Retrieved from <https://www.cia.gov/ library/publications/the-world-factbook/geos/sf.html>.

Chersich, M., Wright, C., Venter, F., Rees, H., Scorgie, F., \& Erasmus, B. (2018). Impacts of climate change on health and wellbeing in South Africa. International Journal of Environmental Research and Public Health, 15(9), 1884-1898.

Choongo, P. (2017). A longitudinal study of the impact of corporate social responsibility on firm performance in SMEs in Zambia. Sustainability, 9(8), 1300.

Choongo, P., van Burg, E., Masurel, E., Paas, L. J., \& Lungu, J. (2017). Corporate Social Responsibility motivations in Zambian SMEs. International Review of Entrepreneurship, 15(1), 29-62.

City of Cape Town. (2019). Water outlook 2018 report. Retrieved from < https://resource.capetown.gov.za/ documentcentre/Documents/City\%20research\%20reports\%20and\%20review/Water\%20Outlook\%202018\% 20-\%20Summary.pdf>.

Climate System Analysis Group. (2019). Big six monitor. Retrieved from <http://cip.csag.uct.ac.za/monitoring/bigsix.html >.

Denzin, N. K., \& Lincoln, Y. S. (2011). The Sage handbook of qualitative research. Thousand Oaks, CA: Sage.

DiMaggio, P. J., \& Powell, W. W. (1983). The iron cage revisited: Collective rationality and institutional isomorphism in organizational fields. American Sociological Review, 48(2), 147-160.

DiMaggio, P. J., \& Powell, W. W. (2000). The iron cage revisited institutional isomorphism and collective rationality in organizational fields. Economics meets sociology in strategic management (pp. 143-166). Bingley: Emerald Group Publishing Limited.

Dos Santos, M. J. P. L. (2016). Smart cities and urban areas-Aquaponics as innovative urban agriculture. Urban Forestry and Urban Greening, 20, 402-406.

Durrheim, K., Mtose, X., \& Brown, L. (2011). Race trouble: Race, identity and inequality in post-apartheid South Africa. Lanham, MD: Lexington Books.

Edmondson, A. C., \& McManus, S. E. (2007). Methodological fit in management field research. Academy of Management Review, 32(4), 1246-1264.

Eijdenberg, E. L. (2016). Does one size fit all? A look at entrepreneurial motivation and entrepreneurial orientation in the informal economy of Tanzania. International Journal of Entrepreneurial Behavior and Research, 22(6), 804-834.

Eijdenberg, E. L., Thompson, N. A., Verduijn, K., \& Essers, C. (2019). Entrepreneurial activities in a developing country: An institutional theory perspective. International Journal of Entrepreneurial Behavior and Research, 25(3), 414-432.

Favretto, N., Dougill, A., Stringer, L., Afionis, S., \& Quinn, C. (2018). Links between climate change mitigation, adaptation and development in land policy and ecosystem restoration projects: Lessons from South Africa. Sustainability, 10(3), 779.

Flatø, M., Muttarak, R., \& Pelser, A. (2017). Women, weather, and woes: The triangular dynamics of femaleheaded households, economic vulnerability, and climate variability in South Africa. World Development, $90,41-62$.

Gartner, W. B. (1988). "Who is an entrepreneur?" is the wrong question. American Journal of Small Business, 12(4), 11-32.

Gehman, J., Glaser, V. L., Eisenhardt, K. M., Gioia, D., Langley, A., \& Corley, K. G. (2018). Finding theory-method fit: A comparison of three qualitative approaches to theory building. Journal of Management Inquiry, 27(3), 284-300.

George, G. (2015). Expanding context to redefine theories: Africa in management research. Management and Organization Review, 11(1), 5-10.

George, G., Corbishley, C., Khayesi, J. N. O., Haas, M. R., \& Tihanyi, L. (2016). Bringing Africa in: Promising directions for management research. Academy of Management Journal, 59(2), 377-393. 


\section{CHAPTER 9 SHOWCASING ENTREPRENEURS' RESPONSES}

Gephart, R. P., Jr (2004). Qualitative research and the Academy of Management Journal. Academy of Management Journal, 47(4), 454-462.

Gioia, D. A., Corley, K. G., \& Hamilton, A. L. (2013). Seeking qualitative rigor in inductive research: Notes on the Gioia methodology. Organizational Research Methods, 16(1), 15-31.

Global Entrepreneurship Monitor. (2019a). Data: South Africa. Retrieved from <https://www.gemconsortium. org/data/key-aps $>$.

Global Entrepreneurship Monitor. (2019b). South Africa 2016-2017 national report. Retrieved from <https:// www.gemconsortium.org/report/gem-south-africa-2016-2017-report>.

Greenman, A. (2013). Everyday entrepreneurial action and cultural embeddedness: An institutional logics perspective. Entrepreneurship \& Regional Development, 25(7-8), 631-653.

Griffiths, M. D., Gundry, L. K., \& Kickul, J. R. (2013). The socio-political, economic, and cultural determinants of social entrepreneurship activity: An empirical examination. Journal of Small Business and Enterprise Development, 20(2), 341-357.

Groenewald, T. (2004). A phenomenological research design illustrated. International Journal of Qualitative Methods, 3(1), 42-55.

Hossain, M. (2018). Frugal innovation: A review and research agenda. Journal of Cleaner Production, 182, 926-936.

Jojo. (2019). Jojo: For water, for life. Retrieved from <https://www.jojo.co.za/>.

Khan, R. (2016). How frugal innovation promotes social sustainability. Sustainability, 8(10), 1034.

Khanna, T., \& Palepu, K. (1997). Why focused strategies may be wrong for emerging markets. Harvard Business Review, 75(4), 41-43.

Khavul, S., Bruton, G. D., \& Wood, E. (2009). Informal family business in Africa. Entrepreneurship Theory and Practice, 33(6), 1219-1238.

Khayesi, J. N. O., George, G., \& Antonakis, J. (2014). Kinship in entrepreneur networks: Performance effects of resource assembly in Africa. Entrepreneurship Theory and Practice, 38(6), 1323-1342.

Klapper, L., Laeven, L., \& Rajan, R. (2006). Entry regulation as a barrier to entrepreneurship. Journal of Financial Economics, 82(3), 591-629.

Littlewood, D., \& Holt, D. (2015). Social and environmental enterprises in Africa: Context, convergence and characteristics. The business of social and environmental innovation (pp. 27-47). Cham: Springer.

Littlewood, D., \& Holt, D. (2018). Social entrepreneurship in South Africa: Exploring the influence of environment. Business and Society, 57(3), 525-561.

Mabhaudhi, T., Chibarabada, T., Chimonyo, V., Murugani, V., Pereira, L., Sobratee, N., ... Modi, A. (2019). Mainstreaming underutilized indigenous and traditional crops into food systems: A South African perspective. Sustainability, 11(1), 172.

Manolova, T. S., Eunni, R. V., \& Gyoshev, B. S. (2008). Institutional environments for entrepreneurship: Evidence from emerging economies in Eastern Europe. Entrepreneurship Theory and Practice, 32(1), 203-218.

Manolova, T. S., \& Yan, A. (2002). Institutional constraints and entrepreneurial responses in a transforming economy: The case of Bulgaria. International Small Business Journal, 20(2), 163-184.

Mare, F., Bahta, Y. T., \& van Niekerk, W. (2018). The impact of drought on commercial livestock farmers in South Africa. Development in Practice, 28(7), 884-898.

McGee, J. E., Peterson, M., Mueller, S. L., \& Sequeira, J. M. (2009). Entrepreneurial self-efficacy: Refining the measure. Entrepreneurship Theory and Practice, 33(4), 965-988.

Mchunu, N., Lagerwall, G., \& Senzanje, A. (2018). Aquaponics in South Africa: Results of a national survey. Aquaculture Reports, 12, 12-19.

Mdungela, N. M., Bahta, Y. T., \& Jordaan, A. J. (2017). Indicators for economic vulnerability to drought in South Africa. Development in Practice, 27(8), 1050-1063.

Mey, Ld, \& Smit, D. (2013). Advanced research methods. London: Sage Publications.

Muller, M. (2018). Lessons from Cape Town's drought. Nature, 559(7713), 174-176. 
Mutero, J., Munapo, E., \& Seaketso, P. (2016). Operational challenges faced by smallholder farmers: A case of Ethekwini Metropolitan in South Africa. Environmental Economics, 7(2), 40-52.

Naudé, W. A., Gries, T., Wood, E., \& Meintjies, A. (2008). Regional determinants of entrepreneurial start-ups in a developing country. Entrepreneurship and Regional Development, 20(2), 111-124.

North, D. C. (1991). Institutions. Journal of Economic Perspectives, 5(1), 97-112.

Oliver, C. (1991). Strategic responses to institutional processes. Academy of Management Review, 16(1), $145-179$.

Powell, B. (2008). Making poor nations rich: Entrepreneurship and the process of economic development. Palo Alto, CA: Stanford University Press.

Puffer, S. M., McCarthy, D. J., \& Boisot, M. (2010). Entrepreneurship in Russia and China: The impact of formal institutional voids. Entrepreneurship Theory and Practice, 34(3), 441-467.

Rivera-Santos, M., Holt, D., Littlewood, D., \& Kolk, A. (2015). Social entrepreneurship in sub-Saharan Africa. Academy of Management Perspectives, 29(1), 72-91.

Saini, J. S., \& Bhatia, B. S. (1996). Impact of entrepreneurship development programmes. Journal of Entrepreneurship, 5(1), 65-80.

Saunders, M., Lewis, P., \& Thornhill, A. (2016). Research methods for business students. Essex: Pearson Education Limited.

Schiermeier, Q. (2018). Climate as culprit. Nature, 560, 20-22.

Scott, W. R. (1995). Organizations and institutions. Thousand Oaks, CA: Sage.

Sershen, S., Rodda, N., Stenström, T. A., Schmidt, S., Dent, M., Bux, F., ... Fennemore, C. (2016). Water security in South Africa: Perceptions on public expectations and municipal obligations, governance and water re-use. Water SA, 42(3), 456-465.

Shane, S. A. (2003). A general theory of entrepreneurship: The individual-opportunity nexus. Cheltenham: Edward Elgar Publishing.

Smallbone, D., \& Welter, F. (2001). The distinctiveness of entrepreneurship in transition economies. Small Business Economics, 16(4), 249-262.

Social Enterprise Academy South Africa. (2019). Learning and development for social changemakers in South Africa. Retrieved from <https://www.socialenterprise.academy/za/ $>$.

Stenholm, P., Acs, Z. J., \& Wuebker, R. (2013). Exploring country-level institutional arrangements on the rate and type of entrepreneurial activity. Journal of Business Venturing, 28(1), 176-193.

Urbano, D., \& Alvarez, C. (2014). Institutional dimensions and entrepreneurial activity: An international study. Small Business Economics, 42(4), 703-716.

Vogel, C., \& Olivier, D. (2018). Re-imagining the potential of effective drought responses in South Africa. Regional Environmental Change, 19(6), 1561-1570.

Weerawardena, J., \& Mort, G. S. (2006). Investigating social entrepreneurship: A multidimensional model. Journal of World Business, 41(1), 21-35.

Welter, F. (2011). Contextualizing entrepreneurship-Conceptual challenges and ways forward. Entrepreneurship Theory and Practice, 35(1), 165-184.

Welter, F., Baker, T., Audretsch, D. B., \& Gartner, W. B. (2017). Everyday entrepreneurship—A call for entrepreneurship research to embrace entrepreneurial diversity. Entrepreneurship Theory and Practice, 41(3), $311-321$.

Welter, F., Kautonen, T., Chepurenko, A., Malieva, E., \& Venesaar, U. (2004). Trust environments and entrepreneurial behavior-Exploratory evidence from Estonia, Germany and Russia. Journal of Enterprising Culture, 12(4), 327-349.

Welter, F., \& Smallbone, D. (2011). Institutional perspectives on entrepreneurial behavior in challenging environments. Journal of Small Business Management, 49(1), 107-125.

Wennekers, S., Uhlaner, L., \& Thurik, R. (2002). Entrepreneurship and its conditions: A macro perspective. International Journal of Entrepreneurship Education, 1(1), 25-64. 


\section{CHAPTER 9 SHOWCASING ENTREPRENEURS' RESPONSES}

Wicks, D. (2001). Institutionalized mindsets of invulnerability: Differentiated institutional fields and the antecedents of organizational crisis. Organization Studies, 22(4), 659-692.

Wild, S. (2018). South Africa pushes science to improve daily life. Nature, 561(7722), 157-159.

World Bank. (2017). Tourism for development: 20 reasons sustainable tourism counts for development. Retrieved from <http://documents.worldbank.org/curated/en/558121506324624240/pdf/119954-WPPUBLIC-SustainableTourismDevelopment.pdf $>$.

World Bank. (2019a). Doing business: South Africa. Retrieved from < http://www.doingbusiness.org/en/data/ exploreeconomies/south-africa\#DB_sb $>$.

World Bank. (2019b). Gini Index: South Africa. Retrieved from < https://data.worldbank.org/indicator/SI.POV. GINI?locations $=$ ZA> .

Yin, R. K. (2009). Basics of qualitative research: Techniques and procedures for developing grounded theory. Thousand Oaks, CA: Sage Publications.

Zahra, S. A., Wright, M., \& Abdelgawad, S. G. (2014). Contextualization and the advancement of entrepreneurship research. International Small Business Journal, 32(5), 479-500.

Zwane, E. M. (2019). Impact of climate change on primary agriculture, water sources and food security in Western Cape, South Africa. Jàmbá: Journal of Disaster Risk Studies, 11(1), 1-7. 